\title{
Stigmas related to Covid-19 and their prevention
}

$1^{1}$ Tyciana Paolilo Borges, ${ }^{2}$ Renata da Silva Schulz, ${ }^{3}$ Júlia Barbosa de Magalhães, ${ }^{4}$ Luana Moura Campos, ${ }^{5}$ Karla Ferraz dos Anjos, ${ }^{6}$ Darci de Oliveira Santa Rosa I

\footnotetext{
1 Universidade Federal da Bahia. Salvador-BA, Brasil (tycienfa@gmail.com). ORCID: 0000-0003-1784-6937

2 Universidade Federal da Bahia. Salvador-BA, Brasil (renata.s.schulz@gmail.com). ORCID: 0000-0003-4308-7460

${ }^{3}$ Universidade Federal da Bahia. Salvador-BA, Brasil (misuzu.july@gmail.com). ORCID: 0000-0001-9294-8672

${ }^{4}$ Universidade Federal da Bahia. Salvador-BA, Brasil (campos.luanam@gmail.com). ORCID: 0000-0001-5671-1977

${ }^{5}$ Universidade Federal da Bahia. Salvador-BA, Brasil (karla.ferraz@hotmail.com). ORCID: 0000-0002-5453-8303

${ }^{6}$ Universidade Federal da Bahia. Salvador-BA, Brasil (santarosa.darci@gmail.com). ORCID: 0000-0002-5651-2916
}

Received: 30/07/2020

Approved: $17 / 11 / 2020$

Revised: 05/01/2021

DOI: http://dx.doi.org/10.1590/S0103-73312021310103

Coronavirus (SARS-CoV-2) is a virus belonging to the Nidovirales, Coronaviridae family, which was first reported in humans in Wuhan City, Hubei Province, China in 2019 (WHO, 2020a). Because it causes respiratory disease of an infectious nature that requires social distancing and other preventive measures, people who have been affected by the disease have been the target of social stigma.

Covid-19 was attested as a pandemic by the World Health Organization (WHO) in March 2020, and the most affected countries are the United States, Brazil, and Mexico. In Brazil, it is estimated that 8,697,368 people have already contracted the new coronavirus, with 59,119 people having the number of new cases of the disease, which results in a total of 214,147 deaths as of January 21, 2021 (BRASIL, 2021). The increasing number of cases worries health authorities, since the human and material resources to promote recovery, especially in the most serious cases, are considered complex, which can culminate in the collapse of the health system (WHO, 2020b).

To ensure high complexity beds, used for the care needed for infected people, government entities mobilized to expand the number of these beds structured in 
the models of field hospitals. These specialized care centers exclusively serve cases of Covid-19, in order to avoid contagion in hospitalized patients for other reasons, which strictly obey contact isolation and aerosol isolation (BRASIL, 2020).

In this context, the term "Covidário" (in Portuguese Covid-19 Home) used to refer to these specialized centers and services that welcome people with Covid-19 appears. Another example is the less complex services that attend mild cases of the disease, such as the Family Health Strategy. Thus, the term alludes to the "Lepers" - hospital, asylum and sanatorium whose purpose was the mandatory isolation of people affected by leprosy (SINGER; CAMPOS; OLIVEIRA, 1978). This stigma covers patients and health professionals who attend spaces directed to the treatment of Covid-19 cases, which may interfere in the social relationships of these people, as well as in their psychological health.

Similarly, stigmatizations related to the person affected by the disease cover family members, caregivers and friends who are in contact, health professionals working on the front line and Covid-19 treatment centers, which can generate harmful and unfavorable results in the psychosocial context. In addition, the damage to the public health system is added due to the non-adherence and distrust of this potentially stigmatized population, which increases the risk of transmissibility and hinders the tracking of contacts and monitoring of cases (BUDHWANI; SUN, 2020).

The stigma associated with Covid-19 is associated with the use of inadequate terminologies to segregate people infected with SARS-CoV-2 and the spaces in which they are (NASCIMENTO; LEÁO, 2019). In this way, it is essential to understand the way segregation impacts society. Concern about stigmatization follows the Covid-19 discovery begun in China in 2019. With the onset of this disease, the world health authorities were afraid of the inappropriate use of terms, as it could generate stigma attached to affected geographic regions or specific populations (BRUNS; KRAGULJAC; BRUNS, 2020).

Thus, the World Health Organization (WHO) is positioned regarding the adoption of the use of appropriate and recommended words since the researchers of this organization were careful to choose a name for the new coronavirus in order to avoid any kind of stigma. Thus, the terms "Chinese virus", "Wuhan virus" or "Asian virus" should not be used, because it impairs the confrontation of the pandemic, especially regarding efforts to contain the spread of the disease and in the search for health care (WHO, 2020b). 
Despite this position, people of Asian ethnicities began to be avoided or the target of discrimination and hostilities associated with coronavirus. Whereas this delete structure to society may occur in person or online producing negative health outcomes (BUDHWANI; SUN, 2020), campaigns with images with the hashtag "I'm not a virus", began to be broadcast on social media in an attempt to raise awareness about prejudice. Xenophobia has enabled the segregation of Asians and their descendants in an international context, making it difficult to commercialize products of origin and personal relationships (SHU, 2020). The use of phrases with reference to Chinese territories and their population can excite fear and increase discredit in the country's health systems. It is warned that if there is persistence of the use of these stigmatizing and malicious terms, it will be necessary to restore the confidence of marginalized populations (BUDHWANI; SUN, 2020).

It is worth noting that stigma becomes the exclusive regional association when the virus spreads worldwide, so that people who are quarantined become the main target of stereotypes. When affected by negative actions associated with new disease, such as cancellation of social invitations and pejorative comments (BRUNS, KRAGULJAC; BRUNS, 2020), people become vulnerable to the social and psychological effects of distancing. For this reason, it is not uncommon to surface feelings associated with rejection, loneliness and fear (WASSERMAN; GAAG; WISE, 2020).

When these repercussions affect people already considered from vulnerable groups, such as: the elderly, chronic patients, people with disabilities, indigenous and incarcerates communities, the impacts of psychological and social origin can be even greater. Such impacts can also contribute to exacerbation of discriminatory, exclusionary and stigmatizing attitudes, if there are no effective health promotion actions (SMITH; JUDD, 2020). In this sense, health professionals should be aware of the potential for stigmatization of these people in order to sensitize the community to the use of an inclusive and respectful language (BRUNS; KRAGULJAC; BRUNS, 2020; PAHO/WHO, 2020b).

Even in view of the potential of the health professional to minimize the stigma caused by Covid-19, some studies already indicate that this group is also vulnerable. Research indicates cases of stigmatization and discrimination suffered by these professionals, especially in India, Mexico, and the United States of America, in which they were banned from using public transportation, evicted from rented 
apartments, in addition to suffering social ostracism, being insulted on the streets and victims of physical aggression (BAGCCHI, 2020).

Recognizing the harmful character arising from the stigma caused by Covid-19, it is perceived the need to use terms that collaborate for social inclusion and prevent the manifestations of stigmatizing actions and attitudes to minimize the implications for the mental health of people with Covid-19. With this, it was proposed the use of the term "physical distancing" instead of the term "social distancing" (BAGCCHI, 2020). In possession of this new terminology, tied to the educational processes in health regarding the indication of quarantine, it is expected to favor anti-stigmatizing actions.

Health education favors people's knowledge, contributes to improving health, modifying their behaviors and attitudes (SOTGIU et al., 2020), desired and necessary consequences within the context of the new pandemic, especially when it is intended to avoid stigmas. Recently, the director general of WHO declared that all countries should seek a balance between protecting health, preventing disruptions in the social and economic sectors and respecting human rights (WHO, 2020b).

In the meantime, the Ministry of Health and the Pan American Health Organization/World Health Organization (PAHO/WHO) started campaigns through advertisements and videos aimed at promoting mental health of people in the context of Covid-19 and their families. As a product of media broadcasting, a video entitled "Covid-19: a message to you" was structured, which presents information that the virus reaches people regardless of gender markers, race, nationality, and age group bringing elements of psychosocial character, among them the stigma that can be mitigated by encouraging humanization and empathy to those affected by the disease, besides serving as support and encouragement to professionals who are on the front line (PAHO/WHO, 2020a).

Efforts to modify the scenario related to stigma by Covid-19 may also come from government and religious leaders, media, influencers, celebrities, communities and citizens, through the dissemination of simple ideas, understanding that this is a need to be ensured by the Universal Declaration of Human Rights, which in addition to providing ethical guidance, also lays the foundations for responses to public health crises in the future (WHO, 2020b). Therefore, it is essential to support the most vulnerable social classes with restricted access to health services, 
as well as enable information, which is a mobilization from the individual, collective and, therefore, structural point of view. ${ }^{1}$

\section{References}

BAGCCHI, S. Stigma during the COVID-19 pandemic. The Lancet Infectious Diseases, v. 20, n. 7, p. 782-782, 2020. Available at: <https:/www.thelancet.com/pdfs/journals/laninf/PIIS14733099(20)30498-9.pdf>. Retrieved: 23 July 2020.

BUDHWANI, H.; SUN, R. Creating COVID-19 Stigma by Referencing the Novel Coronavirus as the "Chinese virus" on Twitter: quantitative analysis of social media data. Journal of Medical Internet Research, v. 22, n. 5, 2020. Available at: <https://www.ncbi.nlm.nih.gov/pmc/articles/ PMC7205030/?report=reader>. Retrieved: 22 July 2020.

BRASIL. Ministério da Saúde. Coronavírus/Brasil: Painel Coronavírus. 2021. Available at: <https://covid.saude.gov.br/>. Retrieved: 21 Jan. 2021.

. Ministério da Saúde. Secretaria de Atenção Primária à Saúde. Protocolo de manejo clinico do coronavírus (COVID-19) na Atenção Primária à Saúde. 2020. Available at: <http:// docs.bvsalud.org/biblioref/2020/04/1087335/portal-una-sus-especial-covid-19.pdf>. Retrieved: 23 July 2020.

BRUNS, D. P.; KRAGULJAC, N. V.; BRUNS, T. R. COVID-19: facts, cultural considerations, and risk of stigmatization. Journal of Transcultural Nursing, v. 31, n. 4, p. 326-332, 2020. Available at: <https://journals.sagepub.com/doi/pdf/10.1177/1043659620917724>. Retrieved: 23 jul. 2020.

NASCIMENTO, L. A.; LEÃO, A. Estigma social e estigma internalizado: a voz das pessoas com transtorno mental e os enfrentamentos necessários. História, Ciências, Saúde-Manguinhos, Rio de Janeiro, v. 26, n. 1, p. 103-121, mar. 2019. Available at: <https://www.scielo.br/pdf/ hcsm/v26n1/0104-5970-hcsm-26-01-0103.pdf>. Retrieved: 23 July 2020.

ORGANIZAÇÃO PAN-AMERICANA DA SAÚDE. ORGANIZAÇÃO MUNDIAL DA SAÚDE. COVID-19: Uma mensagem para você, 2020. Available at: <https://www.youtube.com/ watch?v=53Cpwbid5sU>. Retrieved: 22 July 2020.

. Ministério da Saúde e OPAS iniciam campanha para promover a saúde mental no contexto da COVID-19. 2020. Available at: <https://www.paho.org/bra/index.php?option=com_conten $\mathrm{t} \&$ view=article \&id=6148:ministerio-da-saude-e-opas-iniciam-campanha-sobre-saude-mentalno-contexto-da-covid-19\&Itemid=839>. Retrieved: 22 July 2020.

SHU, Le. Avoid stigmatizing names for 2019 novel coronavirus. Nature, v. 578, n. 7795, p. 363-363, 2020. Available at: <https://www.nature.com/articles/d41586-020-00458x?proof=trueMay.>. Retrieved: 23 July 2020. 
SINGER, P.; CAMPOS, O.; OLIVEIRA, E. M. Prevenir e curar: o controle social através dos serviços de saúde. 3. ed. Rio de Janeiro: Forense-Universitária, 1988. 166 p.

SMITH, J. A.; JUDD, J. COVID-19: vulnerability and the power of privilege in a pandemic. Health Promotion Journal of Australia, v. 31, n. 2, p. 158-160, 2020. Available at: <https:// onlinelibrary.wiley.com/doi/full/10.1002/hpja.333>. Retrieved: 22 July 2020.

SOTGIU, G. et al. How to demystify COVID-19 and reduce social stigma. The International Journal of Tuberculosis and Lung Disease, v. 24, n. 6, p. 640-642, 2020. Available at: <https:// www.ingentaconnect.com/content/iuatld/ijtld/2020/00000024/00000006/art00022;jsessioni $\mathrm{d}=20$ gleqjrof588.x-ic-live-01\#>. Retrieved: 23 July 2020.

WASSERMAN, D.; VAN DER GAAG, R.; WISE, J. The term "physical distancing” is recommended rather than "social distancing" during the COVID-19 pandemic for reducing feelings of rejection among people with mental health problems. European Psychiatry, v. 63, n. 1, p. 1-2, 2020. Available at: <https://www.cambridge.org/core/services/aop-cambridgecore/content/view/30114ACB22AC710074F59BCF5C5ADCE2/S0924933820000607a. pdf/term_physical_distancing_is_recommended_rather_than_social_distancing_during_ the_covid19_pandemic_for_reducing_feelings_of_rejection_among_people_with_mental_ health_problems.pdf>. Retrieved: 23 July 2020.

WORLD HEALTH ORGANIZATION. Coronavirus disease (Covid-19). Geneva: WHO, 2020a. Available at: <https://www.who.int/docs/default-source/coronaviruse/20200630-covid19-sitrep-162.pdf?sfvrsn=e00a5466_2\&ua=1>. Retrieved: 23 July 2020.

. Addressing Human Rights as Key to the Covid-19 Response. Geneva: WHO, 2020b. Available at: <https://apps.who.int/iris/handle/10665/331811>. Retrieved: 22 July 2020.

\section{Note}

${ }^{1}$ T. P. Borges and R. S. Schulz: construction of the text. J. B. de Magalhães: construction and revision of the text. L. M. Campos and K. F. dos Anjos: construction and final revision of the text. D. O. Santa Rosa: final revision of the text and approval for publication. 